\title{
Russians fear privatization of state labs
}

Bryon MacWilliams, Moscow

Senior officials in Moscow are attempting to reassure Russian scientists about details of a planned reform, under which many hundreds of the country's state research institutes could lose their government funding.

According to a document leaked to the Russian Academy of Sciences last month, the government is focusing on the 450 institutes run by the academy, as well as nearly 2,000 other laboratories run by the government. Russian scientists fear that tens of thousands of them could lose their jobs in the restructuring that is being proposed.

At a hurriedly arranged press conference in Moscow on 18 October, Andrei Fursenko, the minister of education and science, confirmed that the government planned to streamline Russian science. But he said that the details had yet to be determined. "The concept is not a strict directive," he said.

Fursenko added that the ministry and the academy will together determine the criteria by which institutes will be preserved, consolidated, privatized, turned into foundations or simply liquidated. Yury Osipov, president of the Russian Academy of Sciences, said that he will work with the ministry.

The academy was an important scientific powerhouse in Soviet times, although most of its strengths were concentrated in a few disciplines, such as mathematics and weapons science. But it has been criticized in

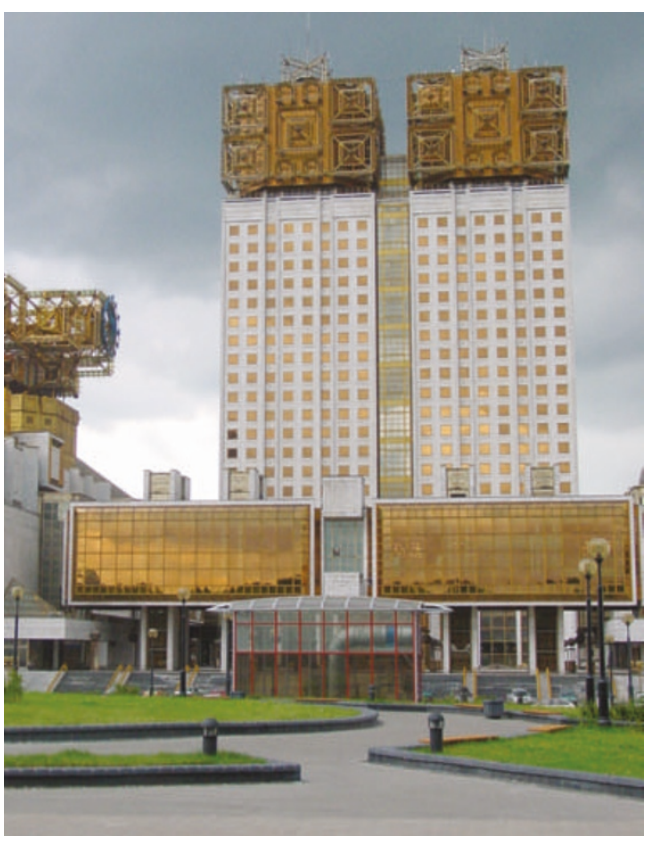

Stark choices: the Russian Academy of Sciences may face major restructuring of its institutes.

recent years for contributing little to industrial innovative power, and for underperformance in basic research.

The need to free up money for applied research has been cited as a driving force behind the planned restructuring. But worried scientists and representatives of trade unions say that they think another factor is at work: the government's desire to generate cash by privatizing land, buildings and patents.
Scientists fear that the restructuring of the academy may provide a pretext for allowing private investors to get their hands on property in one of the world's most expensive real-estate markets.

"We agree that Russian science does need reform," says Boris Stern, a particle physicist at the academy's Institute for Nuclear Research in Moscow. "But we also know that privatization of state property in Russia rarely has the desired effect. It is usually just about selling real estate to businessmen."

Irina Belyaeva, deputy director of the academy's library in St Petersburg, made a similar charge at a press conference on 30 September. "Does the state have the right to privatize the personal property of Peter the Great and his associates?" she asked. She conceded that the library might be unprofitable for the state, but added: "The value of its stock cannot be measured in money."

At Monday's press conference, there was also disagreement over future governance of the academy itself. Fursenko indicated that he views the academy as a state institution in charge of state property, whose leadership should be appointed by, and answerable to, the Russian president, Vladimir Putin. But Osipov said the academy should be only partially beholden to the state and free from "the thumb of bureaucracy".

As Nature went to press, trade unions and state laboratories were planning a protest in Moscow on 20 October.

Additional reporting by Quirin Schiermeier in Munich.

\section{French delegation strengthens bond with China}

David Cyranoski, Tokyo

France and China are a lot closer economically, politically and scientifically — following the French president Jacques Chirac's visit to China earlier this month.

Travelling through the country with a 50-strong French trade delegation, Chirac helped to secure billions of dollars' worth of industrial contracts for France at the same time as signing framework agreements for the promotion of research into environmental protection, the development and peaceful use of atomic energy, health and medical science, nuclear fusion, and the exploration of space.

How such plans will be implemented is not clear, but Chirac's reported desire to "deepen our global partnership with China" is definite.

The new Institut Pasteur of Shanghai, a collaboration between the Paris-based
Institut Pasteur and the Chinese Academy of Sciences, is one of the cornerstones of this partnership. On 11 October, Chirac attended the institute's inauguration with Vincent Deubel, its recently appointed director. Deubel, who is French, is the first foreigner to head a scientific research institute on the Chinese mainland.

The institute, which is expected to open sometime this year, will focus on research into diseases that have devastated parts of China, including AIDS and hepatitis C. It is expected eventually to support 500 scientists, and to be at the centre of China's attempts to deal with its expanding problems with infectious diseases. It should bring top technology and equipment to the country, along with expertise in working in biosafety labs. "Courses on biosafety will be our first duty," says Deubel.

Other partnerships may face a more difficult political future. During Chirac's trip, France and China agreed in principle to work together on space research. This may place France at odds with the United States, which has long blocked Chinese participation in the International Space Station.

During his visit to Shanghai, Chirac told students at Tongji University that France would increase support for Chinese students, saying that the current $\mathbf{8 , 0 0 0}$ students who come to France from China each year are "too few". This move comes at a time when many Chinese students are prevented from going to the United States by its strict immigration policies.

For more news and analysis go to news@nature.com www.nature.com/news 